\title{
Winner Loses All: The 2015 French Regional Elections
}

James Shields

School of Languages and Social Sciences

Aston University

Birmingham

UK

Address for correspondence:

School of Languages and Social Sciences

Aston University

Birmingham

B4 7ET

UK

j.g.shields@aston.ac.uk

0044 (0) 7913092034

The author reports no declarations of interest. 


\begin{abstract}
The French regional elections of 2015 presented two contrasting images of France: in the first round, a political landscape divided into three major blocs with the far-right Front National (FN) the dominant force; in the second round, a landscape as bipolarized between centre-right and centre-left as at any time under the Fifth Republic and with the FN a distant third. This article explores these two representations of political France and analyses the elections in relation to the wider French political context. It discusses the electoral dynamics that enabled the traditional parties to preserve their duopoly of regional power despite the increasingly intrusive challenge to their hegemony mounted by an ever more electorally potent FN.
\end{abstract}

\title{
KEY WORDS
}

France; French elections; regions; regional elections; Front National (FN); political parties 


\title{
Winner Loses All: The 2015 French Regional Elections
}

\author{
James Shields
}

School of Languages and Social Sciences, Aston University, Birmingham, UK

\section{Introduction}

On 6 and 13 December 2015, French voters went to the polls to elect regional councils across metropolitan France and in four of five overseas territories. There are 18 French regions in all: mainland France counts 12, metropolitan France 13 (mainland regions plus Corsica), and the overseas territories of Guadeloupe, Guyane, Martinique, Mayotte and La Réunion make up the remaining 5. All except Mayotte were renewing their assemblies in these elections.

This was the sixth such poll since the decentralization laws of the early 1980s under President François Mitterrand introduced a level of regional government between the departmental and the national. Since then, regional councils (first elected in 1986 and renewed every six years) have become the major agencies in French territorial governance, responsible for regional economic planning and development, transport infrastructure, high-school education, professional training, culture, tourism and European Union (EU) regional policy implementation. There is no hard and fast divide between the competences of regional councils and of the more numerous (101) and smaller-scale departmental councils; both form part of an intricately overlapping architecture of subnational governance, including the yet smaller and much more numerous $(35,500)$ communes and intercommunalities, known as the 'millefeuille territorial' (after the multi-layered pastry cake).

If the structure of French territorial governance is complicated, the financing is more so. Regional and departmental councils benefit from a central government block grant, a decentralization grant and other specific grants-in-aid enabling them to carry out their diverse functions. The rest of their budgets is derived from a variety of local taxes, charges and borrowing. The fiscal autonomy of regional and departmental councils is, however, strictly limited and the proportion of their budgets raised from local taxes is around $20 \%$ for 
departments and $10 \%$ for regions, which rely as a result on central government transfers for some $90 \%$ of their resourcing (Cole, 2017: 152-153).

Focusing mostly on mainland France, this article assesses the significance of the 2015 regional elections within the wider French political context. As the last nationwide poll before the presidential election of April-May 2017, these elections were viewed as an important indicator of the standing of the main parties and potential presidential contenders. The article examines in particular the strong performance by the far-right Front National (FN), which imposed itself as the uncontested winner of the first round only to pay the price of its isolation by failing to take control of a single region in the critical second round. This replicated the two rounds of voting in departmental elections held nine months before, with victory for the FN in the first round followed by sweeping defeat in the second (Shields, 2016). After a brief discussion of the contextual significance of the regional elections, the campaign and voting system, the results of both rounds of voting are analysed and conclusions are drawn in relation to a changing French political environment. As with the departmental elections, the regional elections were effective in keeping the FN out of executive power - but they raised serious questions about democratic representation with the artificial perpetuation of two-party hegemony despite the new realities of a three-party system.

\section{Contextual significance}

The elections of 2015 were of particular significance as the first to be held since a redrawing of the regional map under President François Hollande. This reduced the number of French metropolitan and overseas regions from 27 to 18, with the regions of mainland France being cut from 21 to 12 . The rationale for the reform was threefold: to achieve greater administrative efficiency and cost saving by merging a number of regions into new 'super regions'; to align France's regions more closely in size and strategic purpose with the German Länder as a notional European model; and to couple poorer regions where possible with richer ones, as in the merger of Auvergne and Rhône-Alpes. There was also a concern to reflect, again where possible, something of France's historic regional identities, as in the merging of Haute- and Basse-Normandie into a unified Normandie region and the reconfiguring of the former southern regions of Languedoc-Roussillon and Midi-Pyrénées as 'Occitanie' with Toulouse as 
its capital. Accounting still for $40 \%$ of the communes across the entire EU, France's model of subnational government was hardly transformed by this redrawing of regional boundaries (Cole, 2017: 140, 148-150); but it did raise the stakes in these elections by making the prize of winning regions all the more significant in terms of territorial control.

The other major significance of these elections lay in their timing. Coming less than 18 months before the end of the Hollande presidency (2012-2017), they were the last big electoral test of a deeply unpopular president and a Socialist government failing in its mission to relaunch the economy and reverse France's obdurately high unemployment of over 10\%. These elections followed a sequence of municipal, European and departmental elections (March 2014-March 2015) that had seen heavy losses for the Socialists. Just as for these preceding elections, the political climate surrounding the regional poll of December 2015 was one of widespread voter disaffection and an anti-incumbent animus directed both at the governing Socialists and, to a degree, the centre-right opposition Republicans party (LR) led by former President Nicolas Sarkozy.

By contrast to both major parties of government, the far-right FN found itself in a propitious moment. Revitalized under the leadership of Marine Le Pen since 2011, the FN had won control of 11 towns with a collective population of over 400,000 in the municipal elections of March 2014. The European elections that followed in May saw it emerge for the first time as the top party in France with $24.9 \%$ of the vote and 24 seats in the European Parliament compared with 20 seats for the centre-right Union pour un Mouvement Populaire (UMP) (forerunner of the current Republicans) and 13 for the Socialists and allies. The FN topped the poll in five of France's eight Euro-constituencies, finishing first in 16 of the then 22 metropolitan regions and in 71 of the 96 departments (Roger, 2014). Similarly, in the departmental elections of March 2015, the FN came top in both rounds, posting a first-round score of 5.1 million votes and leading in 43 of the 96 metropolitan departments before being outmanoeuvred by the mainstream parties and blocked from winning control of any department (Shields, 2016). Would the regional elections see the FN sustain its upward momentum and finally break through its historic electoral ceiling to win power at the highest subnational level? Polls suggested the party's capacity to capture two or more of the 12 mainland regions - and this, much more than the governing Socialists' woes or centre-right Republicans' prospects, became the question hanging over these elections. 


\section{Campaign and voting system}

Another question, too, hung over the regional poll. The first round of voting took place under a national state of emergency barely three weeks after the terrorist attacks of 13 November 2015 on the Bataclan concert hall and other Paris venues in which 130 people were killed and over 400 wounded. To what extent would these attacks claimed by the Islamic State group be a factor in the vote, and especially in the performance of the FN with its anti-immigration, antiIslam, hard-line law-and-order and anti-terrorist platform? As the elections approached, a series of regional polls showed Le Pen's party poised to make substantial gains in the wake of the terrorist attacks (BVA, 2015a) and exit polls would confirm this effect (Fourquet and Manternach, 2016a: 36-42).

This apparent electoral boost for the FN was similar to that seen in the departmental elections of March 2015, which had taken place some weeks after the terrorist attacks on the Charlie Hebdo editorial offices and a Jewish supermarket in Paris in January 2015. It also posed the same dilemma for party strategists: to what extent to bring national political issues into the election and to what extent to focus the campaign on regional matters. The result was a blend of the two. Party manifestos reflected prominent regional concerns such as disputed plans for a new airport at Notre-Dame-des-Landes in Pays de la Loire, calls for more high-speed rail links with Bordeaux in Aquitaine-Limousin-Poitou-Charentes ('Nouvelle-Aquitaine'), the effects of deindustrialization in Alsace-Champagne-Ardenne-Lorraine ('Grand Est'), or the vexed issue of migrant squatter camps near Calais in Nord-Pas-de-Calais-Picardie ('Hauts-deFrance'); but they also invoked wider issues of national import such as unemployment and the jobs market, economic growth, immigration, law and order and security. The focus on such 'national' issues far exceeded the realm of regional competences, highlighting the difficulties for political parties of running strictly regional campaigns and appealing to voters' political identification with what is still a relatively new tier in French territorial governance.

The dominant narrative running through the early campaign was the record unpopularity of President Hollande and the failure of his governments to effect economic recovery and bring down unemployment, which had been the signature promise of Hollande's presidential campaign in 2012. In the later campaign, however, the President's ratings did rise for a time in 
response to his handling of the Bataclan atrocity and his success in brokering an international agreement at the Paris climate talks. These elections were also therefore a gauge as to how recoverable Hollande's situation might be with an eye to a bid for re-election in 2017.

Three main parties were in competition: the governing Socialists heading a 'Union of the Left', the opposition Republicans heading a 'Union of the Right', and the FN. In the preceding regional elections of 2010, the then governing centre-right list had topped the first round with $26 \%$ of vote share nationally compared with the Socialists' $23.5 \%$ and the FN's $11.4 \%$. In the second round of those elections, the Socialists had shown a much better capacity than the centre-right to reach beyond their core support and forge a broad-based 'Union of the Left' that won a sweeping victory with $46.4 \%$ of the vote to the centre-right's $35.4 \%$ and the FN's $9.2 \%$. This gave the Socialists and their allies control of almost the entire regional map of France, securing 20 of the then 21 mainland regions and losing only the north-eastern region of Alsace to the centre-right.

Drawing the lessons of 2010, both the Socialists and the Republicans in 2015 sought to present unified fronts of centre-left and centre-right. Their programmes confirmed a strategy to unite around some commonly held broad principles - for the Socialists, an emphasis on social justice and combatting disadvantage, from the fight against discrimination and financial aid for migrants to professional training for the elderly and the expansion of subsidized school bus services; for the Republicans, an emphasis on supporting independent producers and retailers in rural areas, a stepping-up of security in schools and public transport, and a clampdown on drug abuse among lycée students (Le Parisien, 2015).

By contrast with the Socialists and the Republicans, the FN again went into these elections as an isolated party with no capacity to build alliances or to strike even short-term tactical agreements between the two rounds of voting. In its programme, it brought a regional inflection to parts of its 'French first' nationalist agenda, calling for an end to regional aid for multiculturalist and migrant support associations, increased security in public car parks, an 'eat French' policy in school canteens, priority for local businesses in public contract procurement, a halt to job closures in companies receiving regional subsidies, and an end to international cooperation at regional level (Le Parisien, 2015; Auffret and Zerrouky, 2015). 
Isolated within the party system, the FN continued, as in the departmental elections of March 2015, to be at odds with the bipolarizing mechanics of French elections (Knapp and Wright, 2006: 259-261). This isolation had become the key problem it faced as it sought to move beyond being a protest party and become a contender for power. Following its gains in the 2014 municipal elections and first-place performances in the European elections and departmental elections, the regional elections of 2015 raised the question of whether the FN could consolidate its claim to be the 'first party of France' and take control of even a single region as a launch-pad for Le Pen in the presidential contest of April-May 2017.

To do so, the FN would have to overcome not just its isolation vis-à-vis other parties but also an electoral system weighted in favour of the established parties of government and against challenger parties from outside the mainstream. Whereas the regional elections of 1986, 1992 and 1998 had been contested in one round on a strictly proportional basis (a system highly favourable to the FN with its simple seats-for-votes correlation), elections since 2004 employed a more complex two-round system combining majority and proportional elements. Any list winning an outright majority of votes in the first round would secure $25 \%$ of the seats (effectively guaranteeing it a majority in the council), with the rest distributed proportionally above a 5\% threshold on the basis of performance within individual departments. In cases where no first-round majority was achieved (the norm), lists winning $10 \%$ or more of the vote in the first ballot could proceed to the second, where they could fuse with smaller lists having won over 5\%. In the second round, the best placed list would receive $25 \%$ of seats and a proportional share of the rest determined again as above. This system was brought in precisely to produce governing majorities and reduce the influence of the FN within regional councils following its role as arbiter in a number of regions in the 1998 elections (Shields, 2007: 278).

\section{Election results and analysis}


Table 1. Regional elections 2015: first round (all of France)

\begin{tabular}{|l|l|l|l|}
\hline & Number & \% Electoral roll & \% Vote \\
\hline Electoral roll & 45296409 & & \\
\hline Abstention & 22687084 & 50.09 & \\
\hline Voters & 22609325 & 49.91 & \\
\hline Blank ballots & 544767 & 1.20 & 2.41 \\
\hline Spoilt ballots & 356288 & 0.79 & 1.58 \\
\hline Valid votes & 21708270 & 47.92 & 96.01 \\
\hline
\end{tabular}

\begin{tabular}{|c|c|c|c|}
\hline Party/tendency & Votes & \% Electoral roll & $\%$ Valid votes \\
\hline Extreme Left & 334116 & 0.74 & 1.54 \\
\hline Left Front (FDG) & 543935 & 1.20 & 2.51 \\
\hline Communist Party (PCF) & 337410 & 0.74 & 1.55 \\
\hline Europe-Ecology-Greens (EELV)-Left & 607758 & 1.34 & 2.80 \\
\hline Socialist Party (PS) & 62070 & 0.14 & 0.29 \\
\hline Union of the Left & 5019795 & 11.08 & 23.12 \\
\hline Left Radical Party (PRG) & 4227 & 0.01 & 0.02 \\
\hline Diverse Left & 401519 & 0.89 & 1.85 \\
\hline Europe-Ecology-Greens (EELV) & 832487 & 1.84 & 3.83 \\
\hline Ecologist & 127453 & 0.28 & 0.59 \\
\hline Diverse & 226264 & 0.50 & 1.04 \\
\hline Regionalist & 273391 & 0.60 & 1.26 \\
\hline Democratic Movement (MoDem) & 85452 & 0.19 & 0.39 \\
\hline Union of Democrats and Independents & 1818 & 0.00 & 0.01 \\
\hline The Republicans & 42340 & 0.09 & 0.20 \\
\hline Union of the Right & 5785224 & 12.77 & 26.65 \\
\hline Arise France (DLF) & 827211 & 1.83 & 3.81 \\
\hline Diverse Right & 142835 & 0.32 & 0.66 \\
\hline Front National (FN) & 6018904 & 13.29 & 27.73 \\
\hline Extreme Right & 34061 & 0.08 & 0.16 \\
\hline
\end{tabular}


Source: French Interior Ministry (https://www.interieur.gouv.fr/Elections/Lesresultats/Regionales/elecresult_regionales-2015/(path)/regionales-2015/FE.html).

In the first round of voting on 6 December, the FN came first nationally with $27.7 \%$ of the vote, ahead of the Union of the Right on $26.6 \%$ and the Union of the Left on $23.1 \%$ (Table 1). It topped the poll with $30-40 \%$ of the vote in 6 of mainland France's 12 regions: Nord-Pas-deCalais-Picardie, Alsace-Champagne-Ardenne-Lorraine, Bourgogne-Franche-Comté and Centre-Val de Loire in the north and north-east, Languedoc-Roussillon-Midi-Pyrénées and Provence-Alpes-Côte d'Azur in the central and Mediterranean south (Table 2). In a seventh region, Normandie, the FN lost out on first place by just $0.2 \%$, with $27.7 \%$ of the vote to the Union of the Right's $27.9 \%$, a margin of 2,239 votes out of 1.2 million votes cast. Of the other five mainland regions, the Union of the Right claimed first place in three (Auvergne-RhôneAlpes, Île-de-France and Pays de la Loire) and the Union of the Left in two (AquitaineLimousin-Poitou-Charentes and Bretagne).

With over 6 million votes in total, the FN registered its strongest electoral performance ever as a party, coming close to the 6.4 million votes won by Marine Le Pen in the first round of the 2012 presidential election. It more than doubled its first-round score from the previous regional elections of 2010 (11.4\%, 2.2 million votes), and in no mainland region did its vote drop below $18 \%$ (Table 2). In the northern stronghold of Nord-Pas-de-Calais-Picardie, Marine Le Pen's list with $40.6 \%$ opened a lead of over $15 \%$ against the Union of the Right's $25 \%$; in the southern Provence-Alpes-Côte d'Azur, her niece Marion Maréchal-Le Pen's list with 40.5\% took a lead of $14 \%$ against the Union of the Right's $26.5 \%$. In both regions, the Socialist-led Union of the Left came a distant third with $18.1 \%$ and $16.6 \%$ respectively (Table 4 ).

Table 2. FN vote in regional elections 2015: first round (mainland regions)

Region

Nord-Pas-de-Calais-Picardie

Provence-Alpes-Côte d'Azur

Languedoc-Roussillon-Midi-Pyrénées

Alsace-Champagne-Ardenne-Lorraine

Bourgogne-Franche-Comté
FN list leader

Marine Le Pen

Marion Maréchal-Le Pen

Louis Aliot

Florian Philippot

Sophie Montel
FN vote $\% \quad$ FN votes

40.64

909025

40.55

719746

31.83

653573

36.07

641234

31.48

303143 


$\begin{array}{llll}\text { Centre-Val de Loire } & \text { Philippe Loiseau } & 30.48 & 262156 \\ \text { Normandie } & \text { Nicolas Bay } & 27.71 & 317118 \\ \text { Auvergne-Rhône-Alpes } & \text { Christophe Boudot } & 25.52 & 639923 \\ \text { Aquitaine-Limousin-Poitou-Charentes } & \text { Jacques Colombier } & 23.23 & 480621 \\ \text { Pays de la Loire } & \text { Pascal Gannat } & 21.35 & 270888 \\ \text { Ile-de-France } & \text { Wallerand de Saint-Just } & 18.41 & 580499 \\ \text { Bretagne } & \text { Gilles Pennelle } & 18.17 & 218474 \\ \text { France total (all regions) } & \text { Marine Le Pen } & 27.73 & 6018904\end{array}$

Source: French Interior Ministry (https://www.interieur.gouv.fr/Elections/Lesresultats/Regionales/elecresult regionales-2015/(path)/regionales-2015/index.html)

Measured at the departmental level, the FN's performance was equally imposing, with the party coming top in 46 of France's 101 departments and scoring over $40 \%$ in 11 of them, including the southern Var (44.6\%) and Vaucluse (44.2\%), the northern Pas-de-Calais (44.4\%) and Aisne (43.5\%), and the north-eastern Haute-Marne (42.2\%) (Le Monde 2015a). At the most elemental level of all, the FN achieved the astonishing feat of coming first in over 19,000 of France's (then) 36,500 communes (Falga, 2015; Barbier, 2015). In an election where most of those eligible to vote stayed away (with abstention at 50.1\%) (Table 1), the FN once again gave evidence of its ability to get its vote out.

The national aggregate turnout of under $50 \%$ was in line with a long-term decline in voter turnout for all types of election in France, in particular departmental, regional, European and parliamentary (with presidential and municipal elections exerting the strongest mobilizing power). Behind the national figure, however, lay considerable regional variation. Turnout was highest at $54.8 \%$ in Nord-Pas-de-Calais-Picardie, where Marine Le Pen's list was seen to have a strong chance of winning; it was also above the national average in Languedoc-RoussillonMidi-Pyrénées (52.3\%), Provence-Alpes-Côte d'Azur (51.9\%) and Bourgogne-FrancheComté (50.6\%), all likewise regions where the FN looked to have a realistic prospect of victory and where both pro- and anti-FN voters were more mobilized than elsewhere. By contrast, turnout fell to its lowest in Île-de-France with Paris at its heart (45.9\%), a region where no FN factor was at play. As polls across the different regions showed (BVA 2015b), voting for or against the FN was the single most motivating factor in elections characterized by disaffection 
towards the Hollande administration and a less than enthusiastic rallying to the mainstream opposition Republicans.

A number of factors conspired in the FN's favour in this first round. A stagnant economy with unemployment running at 10.2\% (Eurostat, 2016), the migrant crisis, the recent terrorist atrocities with their anti-Muslim backlash, and a generalized mood of public hostility to established elites all allowed the FN to play to its tough law-and-order, national security and economically protectionist populism. Its unprecedented score appeared to vindicate Le Pen's dual strategy of purging her party of its most visibly extremist elements (including her father) and courting disaffected voters feeling abandoned by the mainstream parties. The FN recorded its highest share of support among voters most affected by economic adversity, blue-collar workers (43\%), routine non-manual employees (36\%), small self-employed producers (35\%), and those with low or no educational qualifications (36\%); it also drew a high proportion of support (35\%) from 18-24-year-old voters hard hit by unemployment and poor job prospects (IPSOS, 2015). Support among unemployed voters generally was recorded at $41 \%$ and a strict concordance was found between the lowest levels of income and the highest propensity to vote FN (Perrineau, 2016: 69). This familiar sociological profile of FN voters was combined with the prioritizing of immigration (by 76\%), security (by 74\%) and the fight against terrorism (by $56 \%$ ) as mobilizing issues among FN supporters (Opinionway, 2015).

In policy terms, the headline proposals in the FN programme, with its emphases on economic protectionism, cultural exclusivism and strong-arm law and order, boasted consistency with the party's approach to governing a number of towns since 2014 (Evans and Ivaldi, 2015a). In those towns themselves, FN lists recorded some spectacular first-round results in the regional poll, dispelling the illusion that the exercise of office would expose the party to popular rejection: $59.4 \%$ in Hénin-Beaumont, $59.7 \%$ in Beaucaire, $54.3 \%$ in Cogolin, $53.7 \%$ in Le Pontet, 52.7\% in Le Luc and 50.4\% in Fréjus (Fourquet and Manternach, 2016a: 20).

The second round of these elections thus took on the significance not only of a struggle for regional dominance between centre-left and centre-right, but also of a struggle by the mainstream parties to prevent the FN from translating its first-round advantage into victory in even one region. Three regions stood out as strong possibilities for an FN win - Nord-Pas-deCalais-Picardie, Provence-Alpes-Côte d'Azur and Alsace-Champagne-Ardenne-Lorraine with the first two FN lists under Marine Le Pen and Marion Maréchal-Le Pen almost 
guaranteed victory in three-way run-offs. Faced with that prospect, Socialist party leaders took the extraordinary step of ordering their lists to be withdrawn from the second round in all three of these regions, leaving the field to the Union of the Right and urging left-wing supporters to back it against the FN. Would this be enough to avert an FN win? As voters went to the polls, this was the key question hanging over the second round - a question made more acute by the Socialist Jean-Pierre Masseret's decision in Alsace-Champagne-Ardenne-Lorraine to maintain his Union of the Left list in defiance of the instruction to withdraw from the three-way run-off (Fourquet and Manternach, 2016b: 37-39).

The poll on 13 December saw a consolidated Union of the Right come first with $40.2 \%$ of votes overall and the Union of the Left finish second on $28.9 \%$. The FN came a close third with $27.1 \%$ of votes, the support of $6,820,477$ voters (Table 3 ) - a historic high for the party, exceeding even the 6.4 million won by Marine Le Pen in the presidential election of 2012. On a much raised second-round turnout of $58.4 \%$, the FN added over 800,000 votes to its firstround score, increasing its support across all mainland regions except Île-de-France and tripling its tally of regional councillors (Table 5) from 118 in 2010 to 358 (from a total of 1,722 across mainland regions plus Corsica, with the combined centre-right taking 789, the left 551 and Corsican regionalists 24) (Durand, 2015).

Table 3. Regional elections 2015: second round (all of France)

\begin{tabular}{|l|l|l|l|}
\hline & Number & \% Electoral roll & \% Vote \\
\hline Electoral roll & 45293888 & & \\
\hline Abstention & 18838599 & 41.59 & \\
\hline Voters & 26455289 & 58.41 & \\
\hline Blank ballots & 740458 & 1.63 & 2.80 \\
\hline Spoilt ballots & 547188 & 1.21 & 2.07 \\
\hline Valid votes & 25167643 & 55.57 & 95.13 \\
\hline
\end{tabular}

\begin{tabular}{|l|l|l|l|}
\hline Party/tendency & Votes & \% Electoral roll & \% Valid votes \\
\hline Socialist Party (PS) & 72811 & 0.16 & 0.29 \\
\hline Union of the Left & 7263865 & 16.04 & 28.86 \\
\hline Diverse Left & 746492 & 1.65 & 2.97 \\
\hline
\end{tabular}




\begin{tabular}{|l|l|l|l|}
\hline Party/tendency & Votes & \% Electoral roll & \% Valid votes \\
\hline Regionalist & 136381 & 0.30 & 0.54 \\
\hline Union of the Right & 10127617 & 22.36 & 40.24 \\
\hline Front National (FN) & 6820477 & 15.06 & 27.10 \\
\hline
\end{tabular}

Source: French Interior Ministry (https://www.interieur.gouv.fr/Elections/Lesresultats/Regionales/elecresult_regionales-2015/(path)/regionales-2015/FE.html).

Crucially, the FN failed to win control of any region, repeating its experience from the departmental elections of March 2015. Of the 12 mainland regions, 7 went to the Union of the Right and 5 to the Union of the Left, restoring the bipolarized political landscape which the FN had threatened to disrupt. The 6 non-mainland territorial assemblies were won by a variety of centre-left, centre-right and regionalist lists.

Just as low turnout and a highly mobilized FN vote had marked the first round, a much higher turnout was a determining factor in the second. With $58.4 \%$ participation nationally, some regions saw a surge at the polls, notably those where the FN had won the first round and looked strongly placed for the second - Nord-Pas-de-Calais-Picardie (61.2\% turnout), ProvenceAlpes-Côte d'Azur (60.3\%), Languedoc-Roussillon-Midi-Pyrénées (62\%) and BourgogneFranche-Comté $(61.1 \%)$. The highest rise in turnout was in Alsace-Champagne-ArdenneLorraine (from $47.9 \%$ to 59\%), where FN vice-president Florian Philippot had established a commanding first-round lead. All of these regions demonstrated the mobilizing power of runoff ballots featuring a strongly placed FN, in particular Nord-Pas-de-Calais-Picardie and Provence-Alpes-Côte d'Azur where participation rose by $6.4 \%$ and $8.4 \%$ respectively despite the withdrawal of the Union of the Left list from both. Conversely, the least mobilized secondround electorate was again that of Île-de-France, where polling showed low appreciation of the stakes of these elections and a high level of disengagement (BVA, 2015b), though even here the stronger motivating power of a run-off vote prompted a turnout of $54.5 \%$. 
Table 4. Regional elections 2015: list leaders, results and seats by region (mainland France)

\begin{tabular}{|c|c|c|}
\hline Round 1 & Round 2 & Seats \\
\hline Alsace-Champagne-Ardenne-Lorraine & Alsace-Champagne-Ardenne-Lorraine & \\
\hline Florian Philippot (FN) : $36.07 \%$ & Philippe Richert (UR) : $48.40 \%$ & UR 104 \\
\hline Philippe Richert (UR) : $25.83 \%$ & Florian Philippot (FN) : $36.08 \%$ & $\mathrm{FN} \quad 46$ \\
\hline Jean-Pierre Masseret (UL) : $16.11 \%$ & Jean-Pierre Masseret (DL) : $15.51 \%$ & DL 19 \\
\hline Aquitaine-Limousin-Poitou-Charentes & Aquitaine-Limousin-Poitou-Charentes & \\
\hline Alain Rousset (UL) : $30.39 \%$ & Alain Rousset (UL) : $44.27 \%$ & UL 107 \\
\hline Virginie Calmels (UR) : $27.19 \%$ & Virginie Calmels (UR) : $34.06 \%$ & UR 47 \\
\hline Jacques Colombier (FN) : $23.23 \%$ & Jacques Colombier (FN) : $21.67 \%$ & FN 29 \\
\hline Auvergne-Rhône-Alpes & Auvergne-Rhône-Alpes & \\
\hline Laurent Wauquiez (UR) : $31.73 \%$ & Laurent Wauquiez (UR) : $40.62 \%$ & UR 113 \\
\hline Christophe Boudot (FN) : $25.52 \%$ & Jean-Jack Queyranne (UL) : $36.84 \%$ & UL 57 \\
\hline Jean-Jack Queyranne (UL) : $23.93 \%$ & Christophe Boudot (FN) : $22.55 \%$ & FN 34 \\
\hline Bourgogne-Franche-Comté & Bourgogne-Franche-Comté & \\
\hline Sophie Montel (FN) : $31.48 \%$ & Marie-Guite Dufay (UL) : $34.67 \%$ & UL 51 \\
\hline François Sauvadet (UR) : $24.00 \%$ & François Sauvadet (UR) : $32.89 \%$ & UR 25 \\
\hline Marie-Guite Dufay (UL) : $22.99 \%$ & Sophie Montel (FN) : $32.44 \%$ & FN 24 \\
\hline Bretagne & Bretagne & \\
\hline Jean-Yves Le Drian (UL) : $34.92 \%$ & Jean-Yves Le Drian (UL) : $51.41 \%$ & UL 53 \\
\hline Marc Le Fur (UR) : $23.46 \%$ & Marc Le Fur (UR) : $29.72 \%$ & UR 18 \\
\hline Gilles Pennelle (FN) : $18.17 \%$ & Gilles Pennelle (FN) : $18.87 \%$ & FN 12 \\
\hline Centre-Val-de-Loire & Centre-Val-de-Loire & \\
\hline Philippe Loiseau (FN) : $30.48 \%$ & François Bonneau (UL) : $35.42 \%$ & UL 40 \\
\hline Philippe Vigier (UR) : $26.25 \%$ & Philippe Vigier (UR) : $34.58 \%$ & UR 20 \\
\hline François Bonneau (UL) : $24.31 \%$ & Philippe Loiseau (FN) : $30.00 \%$ & FN 17 \\
\hline Île-de-France & Île-de-France & \\
\hline Valérie Pécresse (UR) : $30.51 \%$ & Valérie Pécresse (UR) : $43.80 \%$ & UR 121 \\
\hline Claude Bartolone (UL) : $25.19 \%$ & Claude Bartolone (UL) : $42.18 \%$ & UL 66 \\
\hline Wallerand de Saint Just (FN) : $18.41 \%$ & Wallerand de Saint Just (FN) : $14.02 \%$ & FN 22 \\
\hline Languedoc-Roussillon-Midi-Pyrénées & Languedoc-Roussillon-Midi-Pyrénées & \\
\hline Louis Aliot $(\mathrm{FN}): 31.83 \%$ & Carole Delga (UL) : $44.81 \%$ & UL 93 \\
\hline Carole Delga (UL) : $24.41 \%$ & Louis Aliot $(\mathrm{FN}): 33.87 \%$ & FN 40 \\
\hline Dominique Reynié (UR) : $18.84 \%$ & Dominique Reynié (UR) : $21.32 \%$ & UR 25 \\
\hline Nord-Pas-de-Calais-Picardie & Nord-Pas-de-Calais-Picardie & \\
\hline Marine Le Pen (FN) : $40.64 \%$ & Xavier Bertrand (UR) : $57.77 \%$ & UR 116 \\
\hline Xavier Bertrand (UR) : $24.97 \%$ & Marine Le Pen $(\mathrm{FN}): 42.23 \%$ & FN 54 \\
\hline Pierre de Saintignon (UL) : $18.12 \%$ & Pierre de Saintignon (UL) : withdrawn & UL -- \\
\hline Normandie & Normandie & \\
\hline Hervé Morin (UR) : $27.91 \%$ & Hervé Morin (UR) : $36.42 \%$ & UR 54 \\
\hline Nicolas Bay $(\mathrm{FN}): 27.71 \%$ & Nicolas Mayer-Rossignol (UL) : $36.08 \%$ & UL 27 \\
\hline Nicolas Mayer-Rossignol (UL) : $23.52 \%$ & Nicolas Bay (FN) : $27.50 \%$ & $\mathrm{FN} \quad 21$ \\
\hline
\end{tabular}


Pays de la Loire

Bruno Retailleau (UR) : $33.49 \%$

Christophe Clergeau (UL) : $25.75 \%$

Pascal Gannat (FN) : $21.35 \%$

Provence-Alpes-Côte d'Azur

Marion Maréchal-Le Pen (FN) : $40.55 \%$

Christian Estrosi (UR) : $26.47 \%$

Christophe Castaner (UL) : $16.59 \%$
Pays de la Loire

Bruno Retailleau (UR) : $42.70 \%$

Christophe Clergeau (UL) : $37.56 \%$

Pascal Gannat (FN) : $19.74 \%$

Provence-Alpes-Côte d'Azur

Christian Estrosi (UR) : $54.78 \%$

Marion Maréchal-Le Pen (FN) : $45.22 \%$

Christophe Castaner (UL) : withdrawn
UR 54

UL 26

FN 13

UR 81

FN 42

UL --

Note: UR: Union of the Right; UL: Union of the Left; FN: Front National; DL: Diverse Left

\section{From winner to loser}

Several factors beyond increased turnout explain the FN's failure to convert first-round supremacy into even partial victory in the second round. The withdrawal of the Socialist-led lists in Nord-Pas-de-Calais-Picardie and Provence-Alpes-Côte d'Azur transformed two highly winnable three-way contests into head-to-head run-offs where the anti-FN vote could coalesce around the Union of the Right (Fourquet and Manternach, 2016b: 27-28). While the FN raised its vote share in both regions by $1.6 \%$ and $4.7 \%$ respectively (106,637 and 166,431 votes) (Table 4), the Union of the Right increased its vote share by some 33\% (830,920 votes) in Nord-Pas-de-Calais-Picardie and by 28\% (603,632 votes) in Provence-Alpes-Côte d'Azur, winning 116 seats to the FN's 54 in the former and 81 seats to the FN's 42 in the latter. Evident here again were the fatal effects for the $\mathrm{FN}$ of facing concerted rather than divided opposition. But even in Alsace-Champagne-Ardenne-Lorraine, where the Socialist leader defied the injunction to withdraw, the FN list gained nothing in vote share between the rounds compared with the Union of the Right's gain of some $22 \%$ (over 600,000 votes) to seal an emphatic victory, with 104 seats to 46 for the FN and 19 for the dissident Union of the Left list (Table 4). 
Table 5. FN vote in regional elections 2015: second round (mainland regions)

$\begin{array}{lllll}\text { Region } & \text { FN list leader } & \text { FN vote \% } & \text { FN votes } & \text { FN seats } \\ \text { Nord-Pas-de-Calais-Picardie } & \text { Marine Le Pen } & 42.23 & 1015662 & 54 \\ \text { Provence-Alpes-Côte d'Azur } & \text { Marion Maréchal-Le Pen } & 45.22 & 886177 & 42 \\ \text { Languedoc-Roussillon-Midi-Pyrénées } & \text { Louis Aliot } & 33.87 & 826114 & 40 \\ \text { Alsace-Champagne-Ardenne-Lorraine } & \text { Florian Philippot } & 36.08 & 790166 & 46 \\ \text { Bourgogne-Franche-Comté } & \text { Sophie Montel } & 32.44 & 376913 & 24 \\ \text { Centre-Val de Loire } & \text { Philippe Loiseau } & 30.00 & 308432 & 17 \\ \text { Normandie } & \text { Nicolas Bay } & 27.50 & 374142 & 21 \\ \text { Auvergne-Rhône-Alpes } & \text { Christophe Boudot } & 22.55 & 667102 & 34 \\ \text { Aquitaine-Limousin-Poitou-Charentes } & \text { Jacques Colombier } & 21.67 & 507789 & 29 \\ \text { Pays de la Loire } & \text { Pascal Gannat } & 19.74 & 286711 & 13 \\ \text { Ile-de-France } & \text { Wallerand de Saint-Just } & 14.02 & 521493 & 22 \\ \text { Bretagne } & \text { Gilles Pennelle } & 18.87 & 246177 & 12 \\ & & & & \\ \text { France total (all regions) } & \text { Marine Le Pen } & 27.10 & 6820477 & 358^{*}\end{array}$

* The FN won 354 seats across the regions of mainland France plus 4 seats in Corsica.

Source: French Interior Ministry (https://www.interieur.gouv.fr/Elections/Lesresultats/Regionales/elecresult_regionales-2015/(path)/regionales-2015/index.html)

This points to a perennial problem for the FN in two-round majoritarian elections: how to grow its own vote sufficiently in second-round run-offs to offset the tactical support that rallies around the party most likely to block the FN. The dynamic is stronger and clearer in two-way run-offs, but it is a feature of three-way run-offs too (Jaffré, 2017). Across all regions, the FN increased its support in these elections by some 800,000 votes; but the Union of the Right rallied an additional 4.3 million votes and the Union of the Left, for all the Socialists' woes in government, an additional 2.2 million.

That absence of rallying power between the rounds remains a critical weakness for the FN, a weakness that has a further dimension in voters who turn out for the second round of voting only. Between the two rounds of these elections, turnout rose by $8.5 \%, 3.8$ million. Of those additional votes, the FN made a net gain of $20 \%$ while $80 \%$ went to opposing lists. For every added vote in support of the FN, there were four votes against. While the electoral system used 
in regional polls - a proportional system with a majoritarian element but with a low run-off threshold - is among the most favourable for the FN, the party suffered also in these elections from a disadvantageous regional spread of votes. With 7,263,865 votes overall in the second round, Union of the Left lists won five regions; with just 443,388 votes fewer $(6,820,477)$, but with a less favourably configured map of regional support, the FN won none (Evans and Ivaldi, 2015b).

\section{Conclusions: regional elections raising national questions}

The 2015 French regional elections raised questions beyond the composition of regional government. They showed a French political landscape dominated by three major political forces, each with around a quarter of the first-round vote: the Socialist-led centre-left $(23.1 \%)$, the Republicans-led centre-right (26.6\%), and ahead of both the far-right FN (27.7\%). Yet the map of France that emerged from these elections, with all 12 mainland regions shared between Republicans and Socialists, perpetuated the traditional image of a bipolarized political landscape with only two major forces at play. This article has discussed the electoral dynamics that enabled the established parties of government to preserve their duopoly of regional power despite the increasingly intrusive challenge to their hegemony mounted by the FN.

This may accord with the institutional logic of the Fifth Republic, forged in a period of political instability to keep non-mainstream parties away from power; but it poses questions over democratic representation when the party with the largest share of the vote nationwide in the first round, and a clear lead locally in more than half of 36,500 communes, emerges with no stake in governing any region. It poses yet more acute questions of disenfranchisement that almost 700,000 Union of the Left voters across Nord-Pas-de-Calais-Picardie and ProvenceAlpes-Côte d'Azur should find their candidates withdrawn by a decision in Paris and should have to resign themselves to having not a single left-of-centre councillor out of the 293 at stake. In these two regions, which the Socialists had previously held, centre-right and far-right lists took exclusive control of both government and opposition with a six-year mandate. The socalled 'republican front' against the FN once functioned as a bipartisan agreement to rally behind the better placed centre-right or centre-left candidates in contests where the FN risked winning against divided opposition. For the first time in these elections it took the form of a 
unilateral sacrifice of all representation across two (in principle three) entire regions. This may have allowed the Socialists to claim the moral high ground but it offered no long-term, democratically viable solution for countering the FN.

Despite the artifice of keeping the FN out of office by a tactical manoeuvre, Le Pen's party emerged strengthened from these elections and with its capacity to make large-scale electoral gains confirmed. As reported by Le Monde, the elections resulted in an FN 'defeated but strengthened' and a 'joyless success' for the mainstream parties (Le Monde, 2015b). Behind the appearance of 'politics as usual', the FN installed itself as the sole opposition in the above two regions and the main opposition in two more (Alsace-Champagne-Ardenne-Lorraine and Languedoc-Roussillon-Midi-Pyrénées), marking a further stage in the party's progressive institutionalization and its cultivation of a new regional elite. It also helped determine the outcome in regions where it finished third, as in Centre-Val de Loire and Bourgogne-FrancheComté where FN pressure on the Republicans enabled narrow wins for the Socialists (Fourquet and Manternach, 2016a: 10-11).

The final lesson of these elections was one no-one saw at the time: that using any election as a gauge of what may happen in the next can be a perilous affair. The results confirmed the continuing dominance of the traditional parties of government within a political landscape as seemingly bipolarized as at any time under the Fifth Republic. President François Hollande emerged buttressed by a better than anticipated Socialist performance and with an improved prospect of running for re-election; Nicolas Sarkozy, despite his Republicans' modest win, remained the man to beat in his party's upcoming presidential primaries; and Marine Le Pen stayed as favourite to win the first round of the presidential election and lose the second. The 2015 regional elections yielded no indication that, 18 months later, this familiar landscape would be abruptly transformed, with Hollande and Sarkozy dethroned, Le Pen overtaken, and with the presidency falling to an independent centrist who had never run for election and the National Assembly to a new centrist movement that did not exist in December 2015. The abiding question of these regional elections, therefore, is whether they marked the end of an old bipolarized order between centre-right and centre-left blocs or whether they merely opened a period of apparent renewal before a return to traditional norms. It may be the next regional elections in 2021 that will provide some elements of an answer. 


\section{Acknowledgement}

The author would like to thank the Leverhulme Trust for a Reseach Fellowship that enabled him to write this article.

\section{Disclosure Statement}

No potential conflict of interest was reported by the author.

\section{References}

Auffret, S. and Zerrouky, M. (2015), Elections régionales: Marine Le Pen pourrait-elle appliquer son programme en Nord-Pas-de-Calais-Picardie?, Le Monde, 11 December.

Barbier, C. (2015), Régionales: une paire de gifles, L'Express, 8 December.

BVA (2015a), Elections régionales 2015. Intentions de vote - Rapport national.

Vague 2 - Novembre 2015, accessed at

http://www.bva.fr/data/sondage/sondage_fiche/1781/fichier_bva_pour_la_presse regionale _regionales_2015_-_intentions_de_vote_-_rapport_national148ae.pdf on 17 November 2017.

BVA (2015b), Elections régionales 2015 - Intentions de vote par région, accessed at http://www.bva.fr/fr/sondages/elections_regionales_2015_intentions_de_vote_par_region.html on 17 November 2017.

Cole, A. (2017), French Politics and Society. 3rd edn. Abingdon/New York: Routledge.

Durand, A-A. (2015), Aux régionales, la gauche perd plus de la moitié de ses élus, Le Monde, 15 December.

Eurostat (2016), Newsrelease - Euroindicators, 24/2016, 2 February, accessed at http://ec.europa.eu/eurostat/documents/2995521/7149413/3-02022016-AP-EN.pdf/ on 17 November 2017.

Evans, J. and Ivaldi, G. (2015a), The FN on the threshold of regional government, 500 Signatures, 11 December, accessed at http://500signatures.net/index.php?id=50 on 17 November 2017. 
Evans, J. and Ivaldi, G. (2015b), Ils ne passeront pas - the stemming of the FN tide in the regional run-offs, 500 Signatures, 14 December, accessed at http://500signatures.net/index.php?id=51 on 17 November 2017.

Falga, P. (2015), Régionales 2015: la poussée du FN en cinq points clés, L’Express, 7 December.

Fourquet, J. and Manternach, S. (2016a), Régionales 2015 (1): Vote FN et attentats. Paris: Fondation pour l'innovation politique, March.

Fourquet, J. and Manternach, S. (2016b), Régionales 2015 (2): Les partis, contestés mais pas concurrencés. Paris: Fondation pour l'innovation politique, March.

French Interior Ministry (2017), Résultats des élections régionales 2015, accessed at https://www.interieur.gouv.fr/Elections/Les-resultats/Regionales/elecresult_regionales2015/(path)/regionales-2015/index.html on 17 November 2017.

IPSOS (2015), Régionales 2015. Sociologie des électorats et profil des abstentionnistes, accessed at https://www.ipsos.com/sites/default/files/files-frfr/doc_associe/sociologie_de_lelectorat_electionsregionales2015_6_decembre_-_20h30.pdf on 17 November 2017.

Jaffré, J. (2017), Le Front National face à l'obstacle du second tour, Paris: Fondation pour l'innovation politique.

Knapp, A. and Wright V. (2006), The Government and Politics of France. 5th edn. Abingdon/New York: Routledge.

Le Monde (2015a), Supplement 'Régionales 2015: Résultats du premier tour', 8 December.

Le Monde (2015b), Un FN défait, mais un FN renforcé: le zapping du second tour des régionales, 14 December.

Le Parisien (2015), Elections régionales: le programme des partis à la loupe, 3 December.

Opinionway (2015), Premier tour des élections régionales 2015: Sur quels critères les Français ont-ils voté?, accessed at http://opinionlab.opinionway.com/dokumenty/OpinionWay-pour-LePoint-Sondage-Jour-du-Vote-Electionsregionales2015-Decembre2015.pdf on 17 November 2017.

Perrineau, P. (2016), Montée en puissance et recompositions de l'électorat frontiste, Pouvoirs, No.157, pp.63-73.

Perrineau, P. (2017), Cette France de gauche qui vote FN. Paris: Seuil.

Roger, P. (2014), Européennes: le FN arrive en tête dans 71 départements, Le Monde, 26 May.

Shields, J. (2007), The Extreme Right in France: From Pétain to Le Pen, Abingdon/New York, Routledge. 
Shields, J. (2016), Departmental elections and the changing landscape of French politics, Regional and Federal Studies, Vol.26, No.3, pp.395-406.

\section{Tables}

Table 1. Regional elections 2015: first round (all of France)

\begin{tabular}{|l|l|l|l|}
\hline & Number & \% Electoral roll & \% Vote \\
\hline Electoral roll & 45296409 & & \\
\hline Abstention & 22687084 & 50.09 & \\
\hline Voters & 22609325 & 49.91 & \\
\hline Blank ballots & 544767 & 1.20 & 2.41 \\
\hline Spoilt ballots & 356288 & 0.79 & 1.58 \\
\hline Valid votes & 21708270 & 47.92 & 96.01 \\
\hline
\end{tabular}

\begin{tabular}{|l|l|l|l|}
\hline Party/tendency & Votes & \% Electoral roll & \% Valid votes \\
\hline Extreme Left & 334116 & 0.74 & 1.54 \\
\hline Left Front (FDG) & 543935 & 1.20 & 2.51 \\
\hline
\end{tabular}




\begin{tabular}{|l|l|l|l|}
\hline Party/tendency & Votes & \% Electoral roll & \% Valid votes \\
\hline Communist Party (PCF) & 337410 & 0.74 & 1.55 \\
\hline Europe-Ecology-Greens (EELV)-Left & 607758 & 1.34 & 2.80 \\
\hline Socialist Party (PS) & 62070 & 0.14 & 0.29 \\
\hline Union of the Left & 5019795 & 11.08 & 23.12 \\
\hline Left Radical Party (PRG) & 4227 & 0.01 & 0.02 \\
\hline Diverse Left & 401519 & 0.89 & 1.85 \\
\hline Europe-Ecology-Greens (EELV) & 832487 & 1.84 & 3.83 \\
\hline Ecologist & 127453 & 0.28 & 0.59 \\
\hline Diverse & 226264 & 0.50 & 1.04 \\
\hline Regionalist & 273391 & 0.60 & 1.26 \\
\hline Democratic Movement (MoDem) & 85452 & 0.19 & 0.39 \\
\hline Union of Democrats and Independents & 1818 & 0.00 & 0.01 \\
\hline The Republicans & 42340 & 0.09 & 0.20 \\
\hline Union of the Right & 5785224 & 12.77 & 26.65 \\
\hline Arise France (DLF) & 827211 & 1.83 & 3.81 \\
\hline Diverse Right & 142835 & 0.32 & 0.66 \\
\hline Front National (FN) & 6018904 & 13.29 & 0.08 \\
\hline Extreme Right & 34061 & \\
\hline
\end{tabular}

Source: French Interior Ministry (https://www.interieur.gouv.fr/Elections/Lesresultats/Regionales/elecresult_regionales-2015/(path)/regionales-2015/FE.html). 
Table 2. FN vote in regional elections 2015: first round (mainland regions)

$\begin{array}{llll}\text { Region } & \text { FN list leader } & \text { FN vote \% } & \text { FN votes } \\ \text { Nord-Pas-de-Calais-Picardie } & \text { Marine Le Pen } & 40.64 & 909025 \\ \text { Provence-Alpes-Côte d'Azur } & \text { Marion Maréchal-Le Pen } & 40.55 & 719746 \\ \text { Languedoc-Roussillon-Midi-Pyrénées } & \text { Louis Aliot } & 31.83 & 653573 \\ \text { Alsace-Champagne-Ardenne-Lorraine } & \text { Florian Philippot } & 36.07 & 641234 \\ \text { Bourgogne-Franche-Comté } & \text { Sophie Montel } & 31.48 & 303143 \\ \text { Centre-Val de Loire } & \text { Philippe Loiseau } & 30.48 & 262156 \\ \text { Normandie } & \text { Nicolas Bay } & 27.71 & 317118 \\ \text { Auvergne-Rhône-Alpes } & \text { Christophe Boudot } & 25.52 & 639923 \\ \text { Aquitaine-Limousin-Poitou-Charentes } & \text { Jacques Colombier } & 23.23 & 480621 \\ \text { Pays de la Loire } & \text { Pascal Gannat } & 21.35 & 270888 \\ \text { Ile-de-France } & \text { Wallerand de Saint-Just } & 18.41 & 580499 \\ \text { Bretagne } & \text { Gilles Pennelle } & 18.17 & 218474 \\ \text { France total (all regions) } & \text { Marine Le Pen } & 27.73 & 6018904\end{array}$

Source: French Interior Ministry (https://www.interieur.gouv.fr/Elections/Lesresultats/Regionales/elecresult_regionales-2015/(path)/regionales-2015/index.html) 
Table 3. Regional elections 2015: second round (all of France)

\begin{tabular}{|l|l|l|l|}
\hline & Number & \% Electoral roll & \% Vote \\
\hline Electoral roll & 45293888 & & \\
\hline Abstention & 18838599 & 41.59 & \\
\hline Voters & 26455289 & 58.41 & \\
\hline Blank ballots & 740458 & 1.63 & 2.80 \\
\hline Spoilt ballots & 547188 & 1.21 & 2.07 \\
\hline Valid votes & 25167643 & 55.57 & 95.13 \\
\hline
\end{tabular}

\begin{tabular}{|l|l|l|l|}
\hline Party/tendency & Votes & \% Electoral roll & \% Valid votes \\
\hline Socialist Party (PS) & 72811 & 0.16 & 0.29 \\
\hline Union of the Left & 7263865 & 16.04 & 28.86 \\
\hline Diverse Left & 746492 & 1.65 & 2.97 \\
\hline Regionalist & 136381 & 0.30 & 0.54 \\
\hline Union of the Right & 10127617 & 22.36 & 40.24 \\
\hline Front National (FN) & 6820477 & 15.06 & 27.10 \\
\hline
\end{tabular}

Source : French Interior Ministry (https://www.interieur.gouv.fr/Elections/Lesresultats/Regionales/elecresult_regionales-2015/(path)/regionales-2015/FE.html). 
Table 4. Regional elections 2015: list leaders, results and seats by region (mainland France)

\begin{tabular}{|c|c|c|}
\hline Round 1 & Round 2 & Seats \\
\hline $\begin{array}{l}\text { Alsace-Champagne-Ardenne-Lorraine } \\
\text { Florian Philippot (FN) : } 36.07 \% \\
\text { Philippe Richert (UR) }: 25.83 \% \\
\text { Jean-Pierre Masseret (UL) }: 16.11 \%\end{array}$ & $\begin{array}{l}\text { Alsace-Champagne-Ardenne-Lorraine } \\
\text { Philippe Richert (UR) : } 48.40 \% \\
\text { Florian Philippot (FN) : } 36.08 \% \\
\text { Jean-Pierre Masseret (DL) : } 15.51 \%\end{array}$ & $\begin{array}{lr}\text { UR } & 104 \\
\text { FN } & 46 \\
\text { DL } & 19\end{array}$ \\
\hline $\begin{array}{l}\text { Aquitaine-Limousin-Poitou-Charentes } \\
\text { Alain Rousset (UL) : } 30.39 \% \\
\text { Virginie Calmels (UR) : } 27.19 \% \\
\text { Jacques Colombier (FN) : } 23.23 \%\end{array}$ & $\begin{array}{l}\text { Aquitaine-Limousin-Poitou-Charentes } \\
\text { Alain Rousset (UL) : } 44.27 \% \\
\text { Virginie Calmels (UR) : } 34.06 \% \\
\text { Jacques Colombier (FN) : } 21.67 \%\end{array}$ & $\begin{array}{lr}\text { UL } & 107 \\
\text { UR } & 47 \\
\text { FN } & 29\end{array}$ \\
\hline $\begin{array}{l}\text { Auvergne-Rhône-Alpes } \\
\text { Laurent Wauquiez (UR) : } 31.73 \% \\
\text { Christophe Boudot (FN) : } 25.52 \% \\
\text { Jean-Jack Queyranne (UL) : } 23.93 \%\end{array}$ & $\begin{array}{l}\text { Auvergne-Rhône-Alpes } \\
\text { Laurent Wauquiez (UR) : } 40.62 \% \\
\text { Jean-Jack Queyranne (UL) : } 36.84 \% \\
\text { Christophe Boudot (FN) : } 22.55 \%\end{array}$ & $\begin{array}{lr}\text { UR } & 113 \\
\text { UL } & 57 \\
\text { FN } & 34\end{array}$ \\
\hline $\begin{array}{l}\text { Bourgogne-Franche-Comté } \\
\text { Sophie Montel (FN) : } 31.48 \% \\
\text { François Sauvadet (UR) : } 24.00 \% \\
\text { Marie-Guite Dufay (UL) : } 22.99 \%\end{array}$ & $\begin{array}{l}\text { Bourgogne-Franche-Comté } \\
\text { Marie-Guite Dufay (UL) : } 34.67 \% \\
\text { François Sauvadet (UR) : } 32.89 \% \\
\text { Sophie Montel (FN) : } 32.44 \%\end{array}$ & $\begin{array}{ll}\text { UL } & 51 \\
\text { UR } & 25 \\
\text { FN } & 24\end{array}$ \\
\hline $\begin{array}{l}\text { Bretagne } \\
\text { Jean-Yves Le Drian (UL) : } 34.92 \% \\
\text { Marc Le Fur (UR) : } 23.46 \% \\
\text { Gilles Pennelle (FN) : } 18.17 \%\end{array}$ & $\begin{array}{l}\text { Bretagne } \\
\text { Jean-Yves Le Drian (UL) : } 51.41 \% \\
\text { Marc Le Fur (UR) : } 29.72 \% \\
\text { Gilles Pennelle (FN) : } 18.87 \%\end{array}$ & $\begin{array}{ll}\text { UL } & 53 \\
\text { UR } & 18 \\
\text { FN } & 12\end{array}$ \\
\hline $\begin{array}{l}\text { Centre-Val-de-Loire } \\
\text { Philippe Loiseau (FN) : } 30.48 \% \\
\text { Philippe Vigier (UR) : } 26.25 \% \\
\text { François Bonneau (UL) : } 24.31 \%\end{array}$ & $\begin{array}{l}\text { Centre-Val-de-Loire } \\
\text { François Bonneau (UL) : } 35.42 \% \\
\text { Philippe Vigier (UR) : } 34.58 \% \\
\text { Philippe Loiseau (FN) : } 30.00 \%\end{array}$ & $\begin{array}{ll}\mathrm{UL} & 40 \\
\mathrm{UR} & 20 \\
\mathrm{FN} & 17\end{array}$ \\
\hline $\begin{array}{l}\text { Île-de-France } \\
\text { Valérie Pécresse (UR) : } 30.51 \% \\
\text { Claude Bartolone (UL) : } 25.19 \% \\
\text { Wallerand de Saint Just (FN) : } 18.41 \%\end{array}$ & $\begin{array}{l}\text { Île-de-France } \\
\text { Valérie Pécresse (UR) : } 43.80 \% \\
\text { Claude Bartolone (UL) : } 42.18 \% \\
\text { Wallerand de Saint Just (FN) : } 14.02 \%\end{array}$ & $\begin{array}{lr}\text { UR } & 121 \\
\text { UL } & 66 \\
\text { FN } & 22\end{array}$ \\
\hline $\begin{array}{l}\text { Languedoc-Roussillon-Midi-Pyrénées } \\
\text { Louis Aliot (FN) : } 31.83 \% \\
\text { Carole Delga (UL) : } 24.41 \% \\
\text { Dominique Reynié (UR) : } 18.84 \%\end{array}$ & $\begin{array}{l}\text { Languedoc-Roussillon-Midi-Pyrénées } \\
\text { Carole Delga (UL) : } 44.81 \% \\
\text { Louis Aliot (FN) }: 33.87 \% \\
\text { Dominique Reynié (UR) }: 21.32 \%\end{array}$ & $\begin{array}{ll}\text { UL } & 93 \\
\text { FN } & 40 \\
\text { UR } & 25\end{array}$ \\
\hline $\begin{array}{l}\text { Nord-Pas-de-Calais-Picardie } \\
\text { Marine Le Pen (FN) : } 40.64 \% \\
\text { Xavier Bertrand (UR) : } 24.97 \% \\
\text { Pierre de Saintignon (UL) }: 18.12 \%\end{array}$ & $\begin{array}{l}\text { Nord-Pas-de-Calais-Picardie } \\
\text { Xavier Bertrand (UR) : } 57.77 \% \\
\text { Marine Le Pen (FN) : } 42.23 \% \\
\text { Pierre de Saintignon (UL) : withdrawn }\end{array}$ & $\begin{array}{lr}\text { UR } & 116 \\
\text { FN } & 54 \\
\text { UL } & --\end{array}$ \\
\hline $\begin{array}{l}\text { Normandie } \\
\text { Hervé Morin (UR) : } 27.91 \% \\
\text { Nicolas Bay (FN) : } 27.71 \% \\
\text { Nicolas Mayer-Rossignol (UL) : } 23.52 \%\end{array}$ & $\begin{array}{l}\text { Normandie } \\
\text { Hervé Morin (UR) : } 36.42 \% \\
\text { Nicolas Mayer-Rossignol (UL) : } 36.08 \% \\
\text { Nicolas Bay (FN) : } 27.50 \%\end{array}$ & $\begin{array}{ll}\text { UR } & 54 \\
\text { UL } & 27 \\
\text { FN } & 21\end{array}$ \\
\hline
\end{tabular}


Pays de la Loire

Bruno Retailleau (UR) : $33.49 \%$

Christophe Clergeau (UL) : $25.75 \%$

Pascal Gannat (FN) : $21.35 \%$

\section{Provence-Alpes-Côte d'Azur}

Marion Maréchal-Le Pen (FN) : $40.55 \%$

Christian Estrosi (UR) : $26.47 \%$

Christophe Castaner (UL) : $16.59 \%$
Pays de la Loire

Bruno Retailleau (UR) : $42.70 \%$

Christophe Clergeau (UL) : $37.56 \%$

Pascal Gannat (FN) : $19.74 \%$

UR 54

UL 26

FN 13

Provence-Alpes-Côte d'Azur

Christian Estrosi (UR) : $54.78 \%$

Marion Maréchal-Le Pen (FN) : $45.22 \%$

UR 81

FN 42

UL --

Note: UR: Union of the Right; UL: Union of the Left; FN: Front National; DL: Diverse Left 
Table 5. FN vote in regional elections 2015: second round (mainland regions)

$\begin{array}{lllll}\text { Region } & \text { FN list leader } & \text { FN vote \% } & \text { FN votes } & \text { FN seats } \\ \text { Nord-Pas-de-Calais-Picardie } & \text { Marine Le Pen } & 42.23 & 1015662 & 54 \\ \text { Provence-Alpes-Côte d'Azur } & \text { Marion Maréchal-Le Pen } & 45.22 & 886177 & 42 \\ \text { Languedoc-Roussillon-Midi-Pyrénées } & \text { Louis Aliot } & 33.87 & 826114 & 40 \\ \text { Alsace-Champagne-Ardenne-Lorraine } & \text { Florian Philippot } & 36.08 & 790166 & 46 \\ \text { Bourgogne-Franche-Comté } & \text { Sophie Montel } & 32.44 & 376913 & 24 \\ \text { Centre-Val de Loire } & \text { Philippe Loiseau } & 30.00 & 308432 & 17 \\ \text { Normandie } & \text { Nicolas Bay } & 27.50 & 374142 & 21 \\ \text { Auvergne-Rhône-Alpes } & \text { Christophe Boudot } & 22.55 & 667102 & 34 \\ \text { Aquitaine-Limousin-Poitou-Charentes } & \text { Jacques Colombier } & 21.67 & 507789 & 29 \\ \text { Pays de la Loire } & \text { Pascal Gannat } & 19.74 & 286711 & 13 \\ \text { Ile-de-France } & \text { Wallerand de Saint-Just } & 14.02 & 521493 & 22 \\ \text { Bretagne } & \text { Gilles Pennelle } & 18.87 & 246177 & 12 \\ & & & & \\ \text { France total (all regions) } & \text { Marine Le Pen } & 27.10 & 6820477 & 358^{*}\end{array}$

* The FN won 354 seats across the regions of mainland France plus 4 seats in Corsica.

Source: French Interior Ministry (https://www.interieur.gouv.fr/Elections/Lesresultats/Regionales/elecresult_regionales-2015/(path)/regionales-2015/index.html) 